\title{
Synthesis and Spectroscopic Characterization of the New Sitting-atop Complexes from Reaction of Zirconyl Nitrate and Free Base meso-Tetraarylporphyrins in Mild Conditions
}

\author{
Hossein Dehghani* and Mohammad Reza Mansoumia \\ Department of chemistry. Faculty of science. Uniersity of Kashan, Kashan 87317-51167. Iran \\ ${ }^{*}$ E-mail: Dehghaniakashanu.ac ir \\ Received April 2, 2009, Accepted June 7, 2009
}

\begin{abstract}
$\Lambda$ scries of sitting-atop ( $\mathrm{SAT}$ ) complexes, [( $\left.\mathrm{ZrO}) \mathrm{H}_{2} \mathrm{t}(\mathrm{X}) \mathrm{pp}\left(\mathrm{NO}_{3}\right)_{2}\right]$, have been prepared via the reactions of free base meso-tctraarylporphyrins, $\mathrm{H}_{2} \mathrm{t}(\mathrm{X}) \mathrm{pp}$, with zirconyl nitrate hydrate, $\mathrm{ZrO}\left(\mathrm{NO}_{3}\right)_{2} \cdot \mathrm{XI}_{2} \mathrm{O}$. The products have been characterized by a variety of methods including ${ }^{\top} H$ NMR, ${ }^{1 .} \mathrm{C}$ NMR, IR and UV-Vis spectroscopies, elemental analysis and conductance measurements. The data indicate that the meso-tetraarylporphyrins coordinate with two pyrrolenine nitrogen atoms to the zirconyl cation located above the distorted porphyrin plane and two protons remain on the pyrrole nitrogens. Such half sandwich-type sitting-atop complexes may be considered as models for the initial steps of the metallation of the macrocycles.
\end{abstract}

Key Words: Porphyrin, Zirconyl, SAT complex, Sitting-atop, Deformation

\section{Introduction}

In recent years, the development of new strategies to improve the synthesis of functionalized porphyrins, metalloporphyrins and sandwich-type complexes of metal bisporphyrim and metal porphyrin-phthalocyanine have been widely studied due to their applications in various fields such as artificial photosynthesis, photodynamic therapy, molecular electronics. chemical sensors, electrocatalysts, DNA binding agents, electrochromism, thermochromism, optical discs, and magnetic materials. ${ }^{1-16}$ In the metallation of porphyrins, depending on size, charge, and spin multiplicity of metal ions, they can fit into the center of the porphyrin ring. forming regular metalloporphyrins, or several of them are located out of the ligand plane, resulting in sitting-atop (SAT) complexes. " For the first time, these complexes were indicated as intermediate in the metallation processes of the protoporphyrin dimethyl ester in chloroform, in which two pyrrolenine nitrogens coordinate to the metal ion and two protons on the pyrrole nitrogens remain. ${ }^{12}$ Deviating from the regular porphyrins, in the sitting-

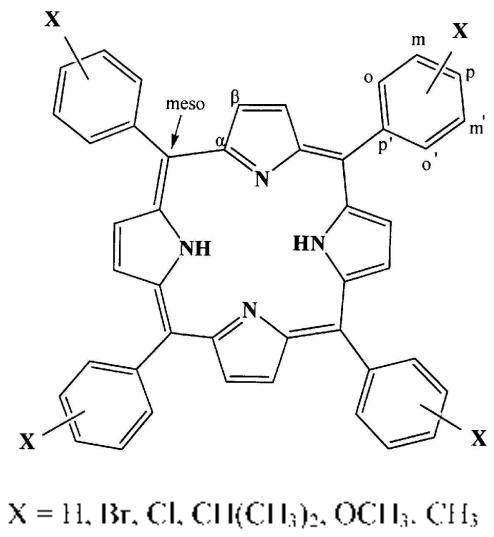

Figure 1. meso-Tetraary]porphyrins $\left(\mathrm{H}_{2} \mathrm{t}(\mathrm{X}) \mathrm{pp}\right)$. atop (SAT) complexes, the ligand plane is distorted and its symmetry lowered. This structure is characterized by special photophysical and photochemical features as well as offers the possibility for formation of bi and even trinuclear (bisporphyrin) complexes. In Interestingly, in the case of lanthanide ions as metal centers, double and triple decker porphyrin sandwich complexes were also synthesized and studied.

In the previous study, we presented the formation of sittingatop complexes from meso-tetraarylporphyrins and uranyl nitrate hexaluydrate. ${ }^{15}$ The high oxidation number of uraniun and using of the suitable solvent (chloroform with very weak basicity) caused that we could be prepared the sitting-atop complexes as stable solids. We have synthesized and characterized new half sandwich-type sitting-atop complexes from meso-tetraarylporphyrins (Figure l) and zirconyl as a smaller ion in mild conditions. The spectroscopic similarities between the produced complexes, the SAT complexes of uranyl $\left.\right|^{15}$ and molecular complexes of meso-tetraarylporphyrins with various acceptors ${ }^{16-1^{1}}$ suggested a similar structure for the porphyrin core in all of the species. In these SAT complexes, one zirconyl is bonded to only two pyrrolenine nitrogens of the porphyrin and the pyrrole protons are not released.

\section{Results and Discussion}

The UV-Vis spectra of the studied meso-tetratylporphyrins show five absorption bands, one soret band (4l6 - 420 $\mathrm{nm}$ ) and four $\mathrm{Q}$ bands ( $515-653 \mathrm{~nm}$ ), that upon the sitting-atop complexation with zirconyl nitrate are shifted to red and appear as two new bands at $44 \mathrm{I}-453$ and $655-687 \mathrm{~nm}$, respectively (Table 1, Figure 2). These red shifts are similar to which were observed for uranyl SAT complexes ${ }^{15}$ and molecular complexes of the porphyrins with various acceptors, ${ }^{16-19}$ and indicate analogous porphyrin cores in all of then. This is related to $\pi$-resonance interaction of the aryl rings with the porphyrin core in the sitting-atop complexes. 
Table 1. LV-Vis and 'H NMR spectral results of the various meso-tetraary lporphyrins and the related sitting-atop complexes.

\begin{tabular}{|c|c|c|c|c|c|}
\hline \multirow{2}{*}{ enlly } & \multirow{2}{*}{$\begin{array}{l}\text { meso-tctraary lporphyrin sitting-atop } \\
\text { complex shifts }\end{array}$} & \multicolumn{2}{|r|}{ t.max $(\mathrm{nm})$} & \multirow{2}{*}{$\mathrm{II}_{\beta}$} & \multirow{2}{*}{$\mathrm{V}-11$} \\
\hline & & Sorct & Q-bands & & \\
\hline \multirow{3}{*}{1} & $\mathrm{H}_{2} t \mathrm{pp}$ & 416.7 & $516.8 .551 .5 .592,0.648 .0$ & 8.85 & -2.76 \\
\hline & {$\left[\mathrm{I}_{2} \mathrm{tpp}(\mathrm{\textrm {rO }})\left(\mathrm{NO}_{3}\right)_{2}\right]$} & 441.9 & 658.3 & 8.70 & -0.43 \\
\hline & $\Delta$ & 25.2 & 10.3 & -0.15 & 2.33 \\
\hline \multirow{3}{*}{2} & $I_{2} \mid(4-\mid 3 r) p p$ & 418.9 & 515.3 .550 .7 .589 .6 .645 .9 & 8.89 & -2.82 \\
\hline & {$\left[\mathrm{H}_{2} \mathrm{t}(4-\mathrm{Br}) \mathrm{pp}(\mathrm{ZrO})\left(\mathrm{NO}_{3}\right)_{2}\right]$} & 445.4 & 658.3 & 8.65 & -0.28 \\
\hline & $\Delta$ & 26.5 & 12.4 & -0.24 & 2.54 \\
\hline \multirow{3}{*}{3} & $\mathrm{H}_{2} \mathrm{t}(4-\mathrm{Cl}) \mathrm{pp}$ & 418.2 & 517.4 .551 .0 .592 .1 .649 .2 & 8.84 & -2.75 \\
\hline & {$\left[\mathrm{H}_{2} \mathrm{t}(4-\mathrm{Cl}) \mathrm{pp} x(\mathrm{ZrO})\left(\mathrm{NO}_{i}\right)_{2}\right]$} & 442.4 & 655.7 & 8.66 & -0.28 \\
\hline & $\Lambda$ & 24.2 & 6.5 & -0.18 & 2.47 \\
\hline \multirow{3}{*}{4} & $\mathrm{H}_{2} \mathrm{t}\left(4-\mathrm{CH}\left(\mathrm{CH}_{3}\right)=\mathrm{pp}\right)$ & 418.9 & 518.0 .553 .3 .592 .3 .648 .6 & 8.87 & -2.74 \\
\hline & {$\left[\mathrm{H}_{2} \mathrm{l}\left(4-\mathrm{Cl}\left(\mathrm{Cl}_{3}\right)_{2}\right) \mathrm{pp}(\mathrm{rO})\left(\mathrm{NO}_{3}\right)_{2}\right]$} & 447.1 & 668.5 & 8.64 & -0.39 \\
\hline & $\Lambda$ & 28.2 & 21.9 & -0.23 & 2.35 \\
\hline \multirow{3}{*}{5} & $\mathrm{I}_{2} \|(3-O C H ;) p p$ & 418.9 & 517.0 .550 .3 .590 .3 .646 .6 & 8.90 & -2.75 \\
\hline & {$\left[\mathrm{I}_{2} 1\left(3-\mathrm{OCl} I_{3}\right) \mathrm{pp}(\mathrm{rO})\left(\mathrm{NO}_{3}\right)_{2}\right]$} & 450.0 & 659.1 & 8.72 & -0.72 \\
\hline & $\Delta$ & 31.1 & 12.5 & -0.18 & 2.03 \\
\hline \multirow{3}{*}{6} & $\mathrm{II}_{2} \|_{\left(4-O C H_{3}\right) p p}$ & 419.5 & $520.5 .557 .1 .596,0.653,0$ & 8.86 & -2.75 \\
\hline & {$\left[\mathrm{H}_{2} \mathrm{t}\left(4-\mathrm{OCH}_{3}\right) \mathrm{pp}(\mathrm{ZrO})\left(\mathrm{NO}_{3}\right)_{2}\right]$} & 452.6 & 686.8 & 8.55 & $-0.2 \mathrm{I}$ \\
\hline & $\Delta$ & 33.1 & 33.8 & -0.31 & 2.54 \\
\hline \multirow{3}{*}{7} & $\mathrm{H}_{2} \mathrm{t}\left(3-\mathrm{CH}_{3}\right) \mathrm{pp}$ & 418.2 & 517.5 .550 .6 .590 .0 .647 .2 & 8.88 & -2.75 \\
\hline & {$\left[\mathrm{H}_{2} \mathrm{t}\left(3-\mathrm{CH}_{i}\right) \mathrm{pp}(\mathrm{ZrO})\left(\mathrm{NO}_{i}\right)_{2}\right\rfloor$} & 443.6 & 659.1 & 8.67 & -0.49 \\
\hline & $\Lambda$ & 25.4 & 11.9 & -0.21 & 2,26 \\
\hline \multirow{3}{*}{8} & $\mathrm{H}_{2} \mathrm{t}(4-\mathrm{CH} ;) \mathrm{pp}$ & 418.3 & 518.4 .554 .0 .593 .0 .649 .0 & 8.85 & -2.77 \\
\hline & {$\left[\mathrm{H}_{2}\left(4-\mathrm{CI}_{3}\right) p p(\mathrm{rO})\left(\mathrm{NO}_{3}\right)_{2}\right]$} & 452.6 & 686.8 & 8.63 & -0.41 \\
\hline & $\Lambda$ & 34.3 & 37.8 & -0.22 & 2.36 \\
\hline
\end{tabular}

A: Shifts in the positions of absorption bands and $\beta$ and $\mathrm{VH}$ protons of the meso-traarylporplyyrins upon the sitting-atop compexation.

In the ${ }^{~} \mathrm{H}$ NMR spectra, the $\mathrm{N}-\mathrm{H}$ and the $\beta$-protons for the meso-tetraarylporphyrins. $\mathrm{H}_{2} \mathrm{t}(\mathrm{X}) \mathrm{pp}$, are upfield $(-2.74$ to $-2.82 \mathrm{ppm})$ and downtield $(8.84$ to $8.90 \mathrm{ppm})$, respectively. The formation of sitting-atop (SAT) complex of these porphyrins with zirconyl caused downfield shifts for the proton

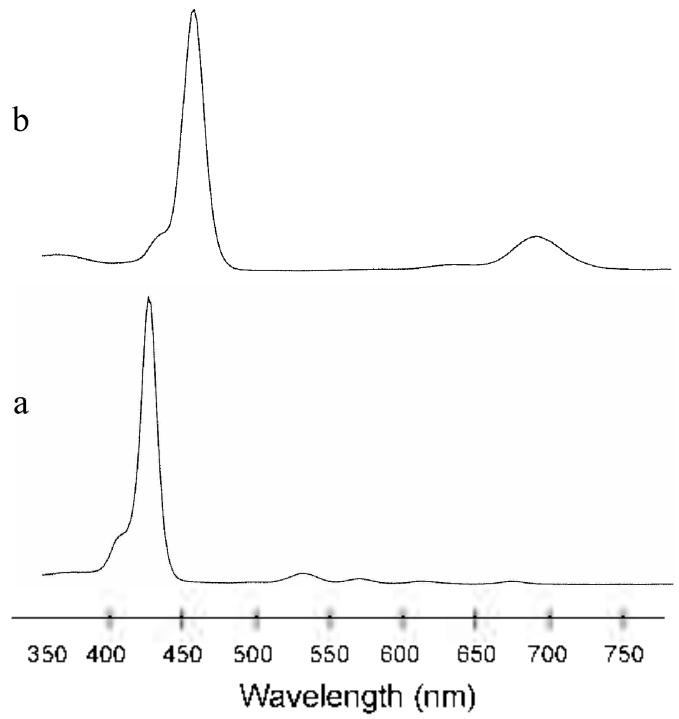

Figure 2. liv-Vis spectra (absorbance-wavelength) ol (a) $1 \mathrm{I}_{2} \mathrm{lpp}$ (b) $\left[\mathrm{H}_{2} \mathrm{tpp}(\mathrm{ZrO})\left(\mathrm{NO}_{3}\right)_{2}\right]$. signals of $\mathrm{N}-\mathrm{H}$ and aryl rings, and upfield shift of the $\beta$ hydrogens, Figure 3 . These changes are similar to the observed shifts upon the SAT complexation of the meso-tetraarylporphyrins with uranyl and so the molecular complexation of them with various acceptors. ${ }^{15-119}$ Therefore, the shifts of $\mathrm{N}-\mathrm{H}$ and $\beta$-protons in the SAT complexes are because of the ring current difference between meso-teraary lporphyrins and their sitting-atop complexes with zirconyl. In the SAT complexes. the effect of ring current for the porphyrins is lost. This may be related to change of the $22 \pi$-electrons system of porphyrin
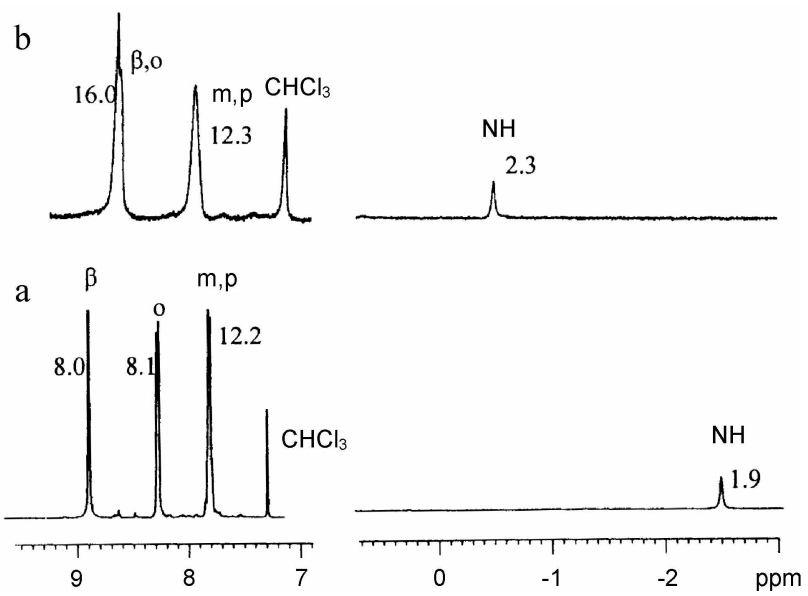

Figure 3. ' $\mathrm{H} N M R$ spectra of (a) $\mathrm{H}_{2}$ tpp (b) $\left[\mathrm{H}_{2} \mathrm{tpp}(\mathrm{ZrO})\left(\mathrm{NO}_{3}\right)_{2}\right]$. 
core to $18 \pi$-electrons in the sitting-atop complexes. Also, the downfield shifts of the aryl ring hydrogens for the complexes can be because of increasing the ring current of aryl rings and comelate to extension of the aryl $\pi$-system in the SAT complexes. $^{1 ?}$

${ }^{1.3} \mathrm{C}$ NMR spectrum of $\mathrm{H}_{2}$ tpp gives rise to six sharp signals

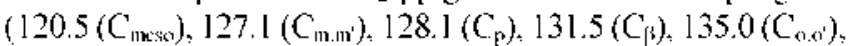
$142.6\left(\mathrm{C}_{\mathrm{n}}\right) \mathrm{ppm}$ ) and a very broad signal $(145.0 \mathrm{ppm})$ for $a-$ carbons, whereas the related SAT complex, $\left[\mathrm{H}_{2} \operatorname{tpp}(7 \mathrm{rO})\left(\mathrm{NO}_{3}\right)_{2}\right]$, shows seven signals at aromatic region, $\left(123.1\left(C_{\text {musio }}\right), 128.4\right.$ $\left(\mathrm{C}_{\mathrm{mln}}\right), 128.8\left(\mathrm{C}_{\mathrm{F}}\right), 130.1\left(\mathrm{C}_{\beta}\right), 138.8\left(\mathrm{C}_{\mathrm{rr},(s)}\right), 139.8\left(\mathrm{C}_{\mathrm{p}}\right)$, and 146.3 (C.. ppm ). Figure 4 . The sitting-atop complexes of the mexotetraarylporphyrins with zirconyl nitrate sharpens the asignals in the ". N.MR spectra of the porphyrins and leads to small shifts in the other lines. These changes are quite similar to that happened in the molecular complexes of meso-letraarylporplyyrins witl $\mathrm{SbCl}_{3}$ and $\mathrm{BiCl} \mathrm{l}_{3}$ acceptors. ${ }^{16.1 \text { ? }}$

The spectral correspondences (UV-Vis, ${ }^{3} \mathrm{H}$.V.MR and ${ }^{13} \mathrm{C}$ $N M R)$ for $\left[\mathrm{l}_{2} \mathrm{t}(\mathrm{X}) \mathrm{pp}(\mathrm{Zr} \mathrm{C})\left(\mathrm{NO}_{3}\right)_{2}\right]$ and $\left[\left(\mathrm{UO}_{2}\right) \mathrm{I} \mathrm{l}_{2} \mathrm{t}(\mathrm{X}) \mathrm{pp}\right]\left(\mathrm{NO}_{3}\right)_{2}$ SAT complexes ${ }^{17}$ and the molecular complexes of the mesotetraarylporphyrins with the various acceptors. ${ }^{1(i-]^{1 !}}$ suggest the similar structure of porplyyrin core in all of them. In the proposed structure, the noncoplanar pyrtole rings tilted alternately up and down and the lone pairs of two pyrrolenine nitrogens acted as the clectron donors to one zirconyl group in a side of the mean plane of the porphyrin, Figure 5.

In accordance with the occurred changes in the UV-Vis, 'I]

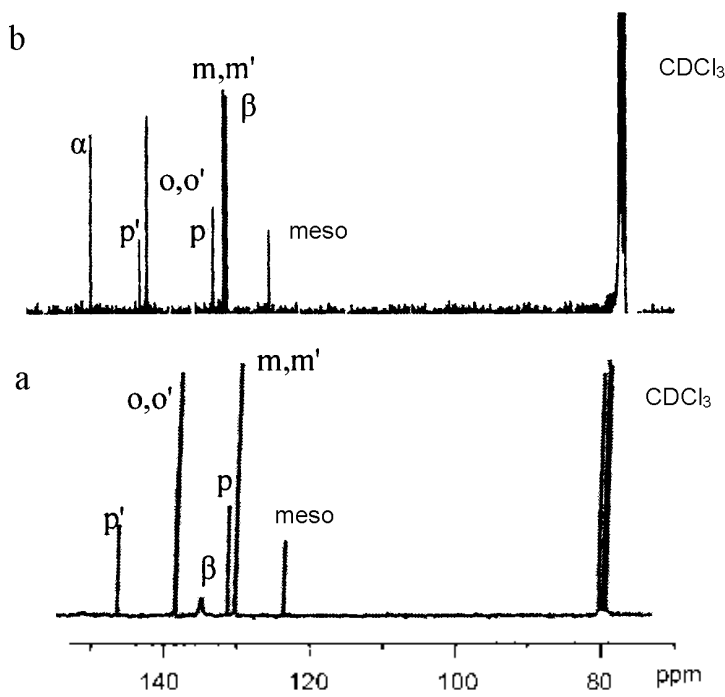

Figure 4. '"C NMR spectra of (a) $\mathrm{H}_{2} \operatorname{tpp}$ (b) $\left[\mathrm{H}_{2} \operatorname{tpp}(\mathrm{ZrO})\left(\mathrm{NO}_{3}\right)_{2}\right]$

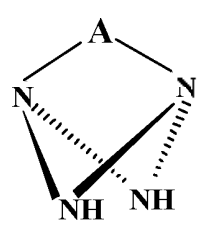

ligure 5. The tetrahedrally tilted py rrolenine nitrogens of a porphyrin core: two nitrogen atoms of pyrrolenine in one side of the porphyrin plane act as the electron donors to the acceptor $\left(\mathrm{A} \mathrm{ZrO}\left(\mathrm{NO}_{3}\right)_{2}\right)$.
NMR and ${ }^{1.3} \mathrm{C}$ NMR spectra of the meso-tetraarylporphyrins on the reaction with zirconyl nitrate, more steric hindrance for mefa-substituents of the aryl rings in the porplyyrins than para-substituents decreases the electron donation of it. Futher, the sitting-atop complexes contain ortho-substituted mesotetraarylporphyrins were not produced in our reaction system. This is related to steric hindrance in these porphyrins.

In the infrared spectrum of $\mathrm{ZrO}\left(\mathrm{NO}_{3}\right)_{2}: \mathrm{HH}_{2} \mathrm{O}$, the intense band at $c a .1 .384 \mathrm{~cm}^{-1}$ is attributed to ionic $\mathrm{NO}_{3}^{-}$, whereas the related SAT complexes with the porphyrins show two additional bands al ca. 1280 and $1480 \mathrm{~cm}^{-1}$, suggesting the coordination of the nitrate groups to the zirconyl center. ${ }^{20.21}$ Furthermore, the F"l-IR spectra show a $\mathrm{N}-\mathrm{H}$ stretching band at $c a .3320 \mathrm{~cm}^{-1}$ (without intramolecular or intemolecular hydrogen bonding) for free base porplyrins, ${ }^{27}$ that upon the complexation with zirconyl nitrate does not change. On the other hand, conductivity measurements showed that the sitting-atop complexes behaved as electrolytes in methanol and nonelectrolytes in acetonitrile. This indicates that the complexes were dissociated to the nitrates and zirconyl-porphyrin cation in methanol but remained neutral and undissociated in acetonitrile. ${ }^{23}$. Ihis is in accordance with the results obtained from the IR studies and proposed formula. Therefore, according to spectroscopic, conductometric and elemental analysis data, the sitting-atop complexation occurred in our reaction system.

\section{Conclusion}

The sitting-atop (SAT) complexes can be produced in the metallation process of porphyrins. Deviating from the regular metalloporphyrins, depending on size, charge, and spin multiplicity of metal ions, the metal centers are located out of the ligand plane, distorting it and causing lower symmetry. We have successfully performed the sitting-atop complexation belween zirconyl and meso-telraarylporphyrins by grinding in a small amount of methanol at ambient temperature. These mild conditions are caused that the reaction do not progress until the metallation of porphyin and stopped in the intermediate step, in which two pyrrolenine nitrogens coordinate to the metal ion and wo protons on the pytrole nitrogens still remain.

\section{Experimental}

Bellzaldehydes and zirconyl nitrate hydrate, $\mathrm{ZrO}\left(\mathrm{NO}_{3}\right)_{2}$. $\mathrm{xH}_{2} \mathrm{O}$ ( $\mathrm{x}$ is $32 \%$ determined gravinetrically), were commercial products obtained from Merck and Fluka, respectively, and were used without further purifications. Pyrrole was purchased from Merck and distilled. Chloroform (Merck) was dried over anlydrous calcium chloride for 3 days and distilled before use. (Other solvents that were employed for the synthesis of the porphyrins and sitting-atop complexes were obtained from Merck and were used as received. meso-Tetraphenylporphyrin and its substituled derivatives were prepared and purified by usual methods. ${ }^{2+}$

The electronic absorption spectra were obtained in chloroform by an ATI UNICAM-UVVis Vision SOFTWARE: V-201 I spectrophotometer. The ${ }^{1} \mathrm{H}$ and ${ }^{1.3} \mathrm{C}$ NMR spectra were recorded 
on a Bruker $400 \mathrm{MHz}$ spectrometer in $\mathrm{CDCl}_{3}$. The residual $\mathrm{CHCl}_{3}$ in the conventional $99.8 \%$ atom $\mathrm{CDCl}_{3}$ gives a signal at $\hat{o}=7.26 \mathrm{ppm}$. which was used for calibration of the chemical shift scale. The FT-IR spectra were recorded on a Magna 550 Nicolet spectrometer using $\mathrm{KBr}$ pellets in the range of $400-4000 \mathrm{~cm}^{-1}$. Molar conductivity data of freshly prepared $\mathrm{I} \times 10^{-3} \mathrm{~mol} / \mathrm{dm}^{3}$ solutions in methanol and acetonitrile were measured at room temperature by a METROHM $6+4$ conductometer.

In a typical reaction. $0 .+$ mmole meso-tetraary lporphy rin (presented in Figure 1) and 0.5 mmole $\mathrm{ZIO}_{\mathrm{I}}\left(\mathrm{NO}_{3}\right)_{-} \times \mathrm{H}_{2} \mathrm{O}$ $(0.170$ g. $25 \%$ excess) grinded in a mortar at ambient temperature. with dropwise adding of $1 \mathrm{~mL}$ methanol during 20 - 30 minutes. until complexation was complete that was determined by the disappearance of the Soret band of the related porphyrin in the UV-Vis spectra. The methanol was evaporated and the produced solid dissolved in clloroform and filtered for removing of the unreacted zirconyl nitrate from the SAT complex (zirconyl nitrate is insoluble in chloroform). After the evaporation of the filtrate and drying under vacuum at 60 ${ }^{\circ} \mathrm{C}$ for $12 \mathrm{~h}$, the sitting-atop complex was obtained as a green solid and was identified by elemental analỵsis. molar conductivity and spectroscopic data.

$\left.\left[\mathrm{H}_{2} \mathrm{t}\right) \mathrm{p}(\mathbf{Z r O})\left(\mathrm{NO}_{3}\right)_{2}\right]$ : Found: C. 62.25: H. 3.39: N. 10.06 \%. Anal. Calc. for $\mathrm{C}_{44} \mathrm{H}_{31} \mathrm{~N}_{6} \mathrm{O}: \mathrm{Zr}:$ C. $62.47 ; \mathrm{H}, 3.57:$ N. 9.93 \%. ${ }^{l} \mathrm{H} \mathrm{NMR}\left(\mathrm{CDCl}_{3}\right)$ ) $\delta 8.70$ (s. $8 \mathrm{H} . \beta$ ). $\delta 8.66$ (d. $8 \mathrm{H} .0 . \mathrm{o}^{\prime}$ ). $\delta$ $8.03\left(\mathrm{~m}, 8 \mathrm{H}, \mathrm{m}, \mathrm{m}^{\prime}\right) . \hat{o} 8.03(\mathrm{~m}, 4 \mathrm{H}, \mathrm{p}), \hat{\delta}-0.43(\mathrm{~s}, 2 \mathrm{H}, \mathrm{NH})$.

$\left.\left[\mathrm{H}_{2} \mathrm{t}(4-\mathrm{Br})\right]_{1}(\mathrm{ZrO})\left(\mathrm{NO}_{3}\right)_{2}\right]:$ Found: C. 45.29: H. 2.42; N. 7.45\%. Anal. Calc. for $\mathrm{C}_{44} \mathrm{H}_{26} \mathrm{Br}_{4} \mathrm{~N}_{6} \mathrm{O}: \mathrm{Zr}: \mathrm{C} .45 .50: \mathrm{H}$. 2.26: $\mathrm{N}, 7.23 \%{ }^{l} \mathrm{H} \mathrm{NMR}\left(\mathrm{CDCl}_{3}\right): \delta 8.65(\mathrm{~s}, 8 \mathrm{H} . \beta), \delta 8.45$ (d. $8 \mathrm{H}$, o. o') $\delta 7.69$ (d. $\left.8 \mathrm{H} . \mathrm{m} . \mathrm{m}^{\prime}\right) . \dot{\delta}-0.28$ (s. $\left.2 \mathrm{H} . \mathrm{NH}\right)$.

$\left.\left[\mathrm{H}_{2} \mathrm{t}(4-\mathrm{Cl}) \mathrm{p}\right](\mathrm{ZrO})\left(\mathrm{NO}_{3}\right)_{2}\right]:$ Found: C. 53.49; H, 2.45: N. 8.68\%. Anal. Calc for $\mathrm{C}_{44} \mathrm{H}_{26} \mathrm{Cl}_{4} \mathrm{~N}_{6} \mathrm{O}-\mathrm{Z}_{\mathrm{I}}: \mathrm{C}, 53.72 ; \mathrm{H} .2 .66$; N. $8.54 \% .{ }^{1} \mathrm{H} \mathrm{NMR}\left(\mathrm{CDCl}_{3}\right): \delta 8.66$ (s. $\left.8 \mathrm{H} . \beta\right) . \delta 8.55$ (d. $8 \mathrm{H}$. o. o'). $\delta 8.02$ (d. $8 \mathrm{H} . \mathrm{m}, \mathrm{m}^{\prime}$ ). ò -0.28 (s. $2 \mathrm{H}$. NH).

$\left.\left[\mathrm{H}_{2} \mathbf{t}\left(\mathbf{4 - C H}\left(\mathbf{C H}_{3}\right)_{2}\right) \mathbf{p p}\right)(\mathbf{Z r O})\left(\mathbf{N O}_{3}\right)_{2}\right]$ : Found: C. 66.06: $\mathrm{H}$. 5.18; N. 8.53\%. Anal. Calc. for $\mathrm{C}_{56} \mathrm{H}_{34} \mathrm{~N}_{6} \mathrm{O}-\mathrm{Z}_{\mathrm{r}}: \mathrm{C}, 66.31 ; \mathrm{H}$. 5.37: N. 8.29\%. ${ }^{l} \mathrm{H} \mathrm{NMR}\left(\mathrm{CDCl}_{3}\right)$ : ò 8.64 (s. 8H. $\beta$ ). $\delta 8.57$ (d. $8 \mathrm{H}$. o. o'). $\delta 7.88$ (d. $\left.8 \mathrm{H}, \mathrm{m} . \mathrm{m}^{\prime}\right) . \hat{o}-0.39$ (s. $2 \mathrm{H} . \mathrm{NH}$ ).

$\left.\left[\mathrm{H}_{2} \mathrm{t}\left(3-\mathrm{OCH}_{3}\right) \mathrm{p}\right)(\mathrm{ZrO})\left(\mathrm{NO}_{3}\right)_{2}\right]:$ Found: C. 59.42; H. 4.13: N. $8.59 \%$. Anal. Calc. for $\mathrm{C}_{48} \mathrm{H}_{38} \mathrm{~N}_{6} \mathrm{O}_{11} \mathrm{Zr}:$ C. $59.68: \mathrm{H} .3 .96$ : $\mathrm{N}, 8.70 \%$. ${ }^{1} \mathrm{H}$ NMR $\left(\mathrm{CDCl}_{3}\right)$ : ò 8.72 (s. $\left.8 \mathrm{H}, \beta\right)$. ò $8.16(\mathrm{~s}, 4 \mathrm{H}$. o). $\delta 8.16\left(\mathrm{~d} .4 \mathrm{H}, \mathrm{o}^{\prime}\right) . \hat{o} 7.90(\mathrm{t} .4 \mathrm{H}, \mathrm{m}) . \hat{o} 7.52(\mathrm{~d} .4 \mathrm{H} . \mathrm{p}) . \delta+.16$ $\left(5,12 \mathrm{H} . \mathrm{OCH}_{3}\right) . \hat{\delta}-0.72(5,2 \mathrm{H}, \mathrm{NH})$.

$\left.\left[\mathrm{H}_{2} \mathrm{t}\left(+-\mathrm{OCH}_{3}\right) \mathrm{p}\right](\mathrm{ZrO})\left(\mathrm{NO}_{3}\right)_{2}\right]:$ Found: C. $59.45 ;$ H. 3.81: N. $8.83 \%$. Anal. Calc. for $\mathrm{C}_{48} \mathrm{H}_{38} \mathrm{~N}_{6} \mathrm{O}_{11} \mathrm{Zr}: \mathrm{C} .59 .68: \mathrm{H}, 3.96$ : N, 8.70\%. ${ }^{l} \mathrm{H} \mathrm{NMR}\left(\mathrm{CDCl}_{3}\right): \delta 8.55$ (s, 8H. $\beta$ ), ó 8.13 (d. $8 \mathrm{H}$,

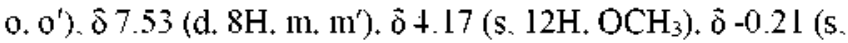
2H. NH).

$\left.\left[\mathrm{H}_{2} \mathbf{t}\left(3-\mathrm{CH}_{3}\right) \mathrm{p}\right)(\mathbf{Z r O})\left(\mathrm{NO}_{3}\right)_{2}\right]$ : Found: C. 64.18: H. 4.11: N. $9.13 \%$. Anal. Calc. for $\mathrm{C}_{48} \mathrm{H}_{38} \mathrm{~N}_{6} \mathrm{O} / \mathrm{Zr}: \mathrm{C} .63 .9 \mathrm{l}: \mathrm{H} .4 .25: \mathrm{N}$. $9.32 \%$. ${ }^{l} \mathrm{H} N \mathrm{NMR}\left(\mathrm{CDCl}_{3}\right): \delta 8.67(5,8 \mathrm{H} . \beta)$, ò $8.44(5,4 \mathrm{H} .0)$, $\delta 8.44\left(\right.$ d. $\left.4 \mathrm{H}, \mathrm{o}^{\prime}\right), \delta 7.90(\mathrm{t}, 4 \mathrm{H}, \mathrm{m}), \delta 7.78(\mathrm{~d} .+\mathrm{H} . \mathrm{p}) . \hat{o} 2.82(\mathrm{~s}$, $\left.12 \mathrm{H}_{3} \mathrm{CH}_{3}\right) . \dot{\delta}-0.49$ (s. $2 \mathrm{H} . \mathrm{NH}$ )

$\left.\left[\mathbf{H}_{2} \mathbf{t}\left(\mathbf{4}-\mathbf{C H}_{3}\right)\right] p(\mathbf{Z r O})\left(\mathbf{N O}_{3}\right)_{2}\right]:$ Found: C. 63.69: H. 4.42: N, $9.59 \%$. Anal. Calc. for $\mathrm{C}_{4} \mathrm{H}_{3} \mathrm{~N}_{6} \mathrm{O}-\mathrm{Zr}: \mathrm{C}, 63.91 ; \mathrm{H} .4 .25 ; \mathrm{N}$, $9.32 \%$. ${ }^{\mathrm{H}} \mathrm{NMR}\left(\mathrm{CDCl}_{3}\right): \delta 8.63$ (s. $8 \mathrm{H} . \beta$ ) $\delta 8.52$ (d. $8 \mathrm{H} .0$. $\left.o^{\prime}\right) . \delta 7.82\left(\mathrm{~d}, 8 \mathrm{H}, \mathrm{m} . \mathrm{m}^{\prime}\right), \delta 2.79\left(\mathrm{~s}, 12 \mathrm{H} . \mathrm{CH}_{3}\right), \delta-0.4 \mathrm{l}(\mathrm{s}, 2 \mathrm{H}$, $\mathrm{NH}$ ).

Aclknowledgments. We are grateful to Kashan University Research Council for their financial support.

\section{References}

1. Bunell, A. K.; Wasielewski, M. R. J. J. Porph Phthal. 2000, 4, 401

2. Pushpan, S. K.: Venkatraman, S.; Anand, V. G.; Sankar, I.; Parmeswaran. D.: Ganesan. S.: Chandrashekar, T. K. Cmr.Med. Chem. 2002, 2, 187

3. Li, Q.; Surthi, S.; Mathur, G.: Gowda, S.: Zhao, Q.: Sorenson, T. A.; Tenent, R. C.: Muthukumaran, K.: Lindsey, J. S:; Misra, V. Appl. Phis. Lett. 2004, 85, 1829

4. Screen, T. E. O.: Blake, I. M.; Rees, L. H.; Clegg, W.: Borwick, S. J.; Anderson, H. L. J. Chen. Soc. Perkin Trans. $12002,320$.

5. A wawdeh, M. A.; Legako, T. A.; Hamon, H. J. Sensor, Actuator B 2003, 91, 27.

6. Araki, K.; Winnischofer, H.; Herbert, H. E. B.; Tovama, M. M; Engelmann, F. M.; Llldemar, F.; Andre, A. L. B.; Toma, H. E. J. Electroanal. Chem. 2004,562, 145

7. Song, R.; Kim, Y.-S.; Soln, Y. S. J. Ihorg. Biochent. 2002, 89, 83 .

8. Nára, M.: Elliott, P.; Swavey, S. Inorg. Chim .4cta 2006, 359 , 2256

9. Tiang, J.: Bao, M.: Rintoul, L.; Amold, D. P. Coord. Chem. Rev' 2006. 250. 424.

10. Liu, Z.; Yasseri, A. A.; Lindsey, T. S.; Bocian, D. F. Science $2003,302,154$

11. Horvath, O.: Huszank, R:; Valicsek, Z: Lendvay, G. Coord. Chem. Rev: 2006, 250, 1792 .

12. Fleischer, E. B.: Wang. J. H. J. Am. Chem. Soc. 1960, 82, 498

13. Hudson, M. F.; Smith, K. M. Chem. Commun. 1973, 515

14. Wittmer, L. L.; Holten, D. J. Phws. Chent 1996, 100, 860.

15. Dehghani, H.: Mansolmia, M. R. Pohhedron 2008, 27, 849

16. Dehghani, H.; Ansari Sardrood, A. R. Bull. Chent. Soc. Ipn. 2007, 80,518 .

17. Dehghani, H.: Ansari Sardrood, A. R. Polyedron 2007, 26, 4263 .

18. Dehghani, H.: Fathi, F. Dyes and Pigments 2008, 77, 323.

19. Dehghani, H.: Fathi. F. J. Porph Phthal. 2007, 11, 849.

20. Nakamoto, K. Infrared and Raman Spectra of Inorganic and Coordination Componds, Fifth ed, Iohn Wiley and Sons Inc:: New York, 1997: Part B.

21. Wyllie, G. R. A.; Munro, O. Q.; Schulz, C. E.; Scheidt, W. R. Polvhedron 2007, 26, 4664.

22. Limbach, H. H.; Henuig, T.; Stulz, J. J. Chent. Phys. 1983, 78 , 5432

23. Geary, W. I. Coord. Chem. Rev. 1971, 7, 81

24. Gonsalves, A. M. D. A. R.; Varejao, T. M. T. B.; Pereira, M. M. J. Heterocycl Chent $1991,28,635$. 